\title{
\begin{tabular}{ll} 
究 \\
\hline
\end{tabular} \\ ウイルスの培養耳管線毛運動に及ぼす影響

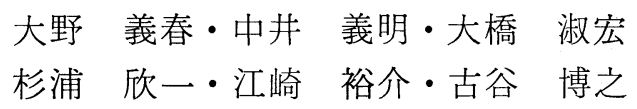

\section{Influence of Influenza A Virus on Ciliary Activity of Cultured Eustachian Tube Mucosa}

\author{
Yoshiharu Ohno, Yoshiaki Nakai, Yoshihiro Ohashi, \\ Yoshikazu Sugiura, Yusuke Esaki and Hiroyuki Furuya \\ (Osaka City University)
}

\begin{abstract}
Clinical investigation suggests that viral infection is involved in middle ear diseases including otitis media with effusion. We studied experimentally the direct effect of influenza A virus on the ciliary activity in the eustachian tube. Guinea pigs with normal otoscopic examination were used. Thin mucosal materials including epithelial layer of the midportion of the eustachian tube were obtained from each animal. Each material was immersed in RPMI 1640 medium. The most active ciliated cell of each culture was selected to be examined for ciliary activity (beats/min) at an ambient temperature of $30^{\circ} \mathrm{C}$. Then each medium was replaced by RPMI 1640 containing a variety of influenza A viruses, and time-course changes of the ciliary activity of cells whose baseline activity was previously determined, up to 48 hours. Some materials cultured in the same fresh RPMI 1640 containing no virus served as controls. In the medium containing low concentrations of virus, ciliated cells did not demonstrate a dramatic decrease of ciliary activity. However, ciliary activity was decreased dramatically in the presence of higher concentrations $\left(3.3 \times 10^{6} \mathrm{PFU} / \mathrm{ml}\right)$, and most cells stopped their beating activity. Cultures exposed to virus were perfused with fresh RPMI 1640 for 12 hours to remove the virus, but quick recovery of the ciliary activity was not observed during observation, up to 12 hours.
\end{abstract}

Key words: ciliary activity, eustachian tube, influenza A virus, tissue culture

\section{緒言}

滲出性中耳炎は幼小児に好発し，中耳液貯留 とこれに付随して難聴をきたす疾患である。 そ の病因について，近年解明が試みられているが, 不明な点む多い.

滲出性中耳炎は急性中耳炎にやや遅れて発症
のピークがあり，滲出性中耳炎患児の多くが急 性中耳炎の既往を有することより，滲出性中耳 炎は急性中耳炎と密接な関係にあることが知ら れている(12). また，急性中耳炎に上気道感染の 先行する頻度の高いととが知られている3 ${ }^{3)}$. し たがって，上気道感染が滲出性中耳炎の発症に 
何らかの形で関与している可能性は高い.

ところで，幼小児の上気道感染においてはウ イルスによるあのが高頻度であるととが知られ ている. そてで，上気道炎を惹起しうるウイル スの代表の一つであるインフルエンザ A ウイル スの耳管粘膜に及ぼす影響を解明する目的で, インフルエンザ A ウイルスの耳管粘膜線毛運動 に及ぼす影響を観察した。なお，本研究におい ては，耳管線毛運動に及ぼす直接的な影響を比 較的長期的に観察するために培養耳管粘膜を用 いた in vitro の実験系で観察した。

\section{研究材料および方法}

体重約 250 グラムのハートレー系モルモット 15匹を用いた。 これら動物を断頭し両側耳管全 長を採取し，直ちに培養液 RPMI 16405) 6) 中に 浸した。次いで耳管中央部を採取し，実体顕微 鏡下に眼科用微細メスを用いて厚さ $60 \sim 70 \mu \mathrm{m}$ の粘膜上皮薄片を採取した. 各々の粘膜薄片を RPMI 1640 で充満したローズ・チェンバー(容 積： $3 \mathrm{ml}$ ) 内に封入し，てのようにして総計 30 個の耳管粘膜上皮の組織培養を作成した.

30 個の培養組織を各群 6 個より成る 5 群（対 照群および $\mathrm{A}-\mathrm{D}$ 群）に無作為に分け, 各培養 組織中の最屯運動性の活発な線毛細胞の線毛運 動数 (打 / 分) を大橋 - 中井の電気光学的方法 ${ }^{7)}$ を用いて, 環境温度 $30^{\circ} \mathrm{C}$ で測定し，基準線毛 運動数とした。

次に, 対照群の培養液は新鮮な PRMI 1640 飞置換し, A,B,C,D 群はそれぞれ $3.3 \times 10^{2}, 3.3$ $\times 10^{4}, 3.3 \times 10^{6}, 3.3 \times 10^{8} \mathrm{PFU} / \mathrm{ml}$ の臨床分離 インフルェンザA ウイルスを含む RPMI 1640 に置換した. 5 群30個の組織培養片の基準線毛 運動を測定した細胞の線毛運動数（打／分）を 培養液置換後， $1,2,3,6,12 ， 24 ， 36 ， 48$ 時 間後に, 環境温度 $30^{\circ} \mathrm{C}$ で同様の方法によって 測定し，基準值に対する\%值を算出した.

また，線毛運動の回復性を検討するために， 各種濃度のインフルェンザウイルスを含む培養 液中で48時間培養した直後に，ウイルスを含ま ない培養液 RPMI 1640 亿置換し，その後 12 時
間後まで同様の方法によって線毛運動の回復性 を観察した.

てのようにして得られた個々の線毛運動数よ り平均值と標準偏差值を算出し, 変化が有意で あるか否かは t-testによって統計学的に処理し， 本研究においては， $\mathrm{p}<0.05$ をもって有意差有 りと判定した。なお，培養液は同一濃度のイン フルエンザ A ウイルスを含む培養液と 12 時間毎 に交換した。

\section{成 績}

1. 対照群

インフルエンザを含まない RPMI 1640 で培 養した対照群の線毛運動数は48時間後まで有意 の変化を示さなかった。

\section{2. ウイルス群}

$\mathrm{A}$ 群の線毛運動数は培養12時間後までは対照 群と有意差を認めなかったが，24時間後以降は 対照群よりも有意に低下することが観察された. $\mathrm{B}$ 群の線毛運動数は 6 時間後までは対照群と有 意差を認めなかったが，12時間後以降は有意に 低下を示し，48時間後の線毛運動数は対照群の 約70\%であった．また，C群の線毛運動数は培 養直後より低下傾向を示し，1 時間後であすで に対照群よりも有意に低下していた．24時間後 では C 群の線毛運動数は対照群の50\%で，36時 間以降では線毛運動の停止した細胞屯観察され た. $\mathrm{D}$ 群の線毛運動も培養直後より低下傾向を 示し， 1 時間後ですでに対照群よりも有意の低 下が認められた。 2 時間後には対照群の約 $50 \%$ となり， 6 時間後以降では一部の線毛運動の停 止が観察された．また，D群の線毛運動は 24 時 間以後では完全に停止していることが観察され た(図1).

$\mathrm{A}-\mathrm{D}$ 群の培養液をウイルスを含まない培養 液 RPMI 1640 に置換後には，Aおよび B 群の 線毛運動数は 4 時間後より徐々に回復したが, 12 時間後でもその回復性は有意ではなかった. また，CおよびD群の線毛運動数は全く回復性 を示さなかった（図 2,3 ). 


\section{考察}

中耳・耳管粘膜は気道粘膜と類似の線毛上 皮で構成されており，粘液線毛系を有してい $3^{8) 9}$. したがって，種々の有害因子が侵入した 場合には，粘液線毛運動による有害因子の排除 機能が働いて，中耳・耳管の恒常性を保持する 仕組となっている，とてろが，何らかの原因で 粘液線毛機能が障害されると，機械的な異物排 除機能が低下して，滲出性中耳炎などの種々の 中耳疾患が発生するあのと考えられる10111).
滲出性中耳炎の病態の本質は中耳腔で過剩産 生された液排出障害と考えられ，実際，滲出性 中耳炎患者における中耳・耳管の粘液線毛輸送 速度の遅延ないしは廃絶がラジオアイソトープ を用いた研究より報告されている(2)。乙の粘液 線毛輸送機能は線毛細胞による線毛運動と乙れ を被覆している粘液層の協調作用によって営ま れる機械的な生体防御作用である。したがって， 粘液線毛機能不全は線毛運動の低下，粘液層の 質的・量的変化あるいは線毛と粘液層の協調性

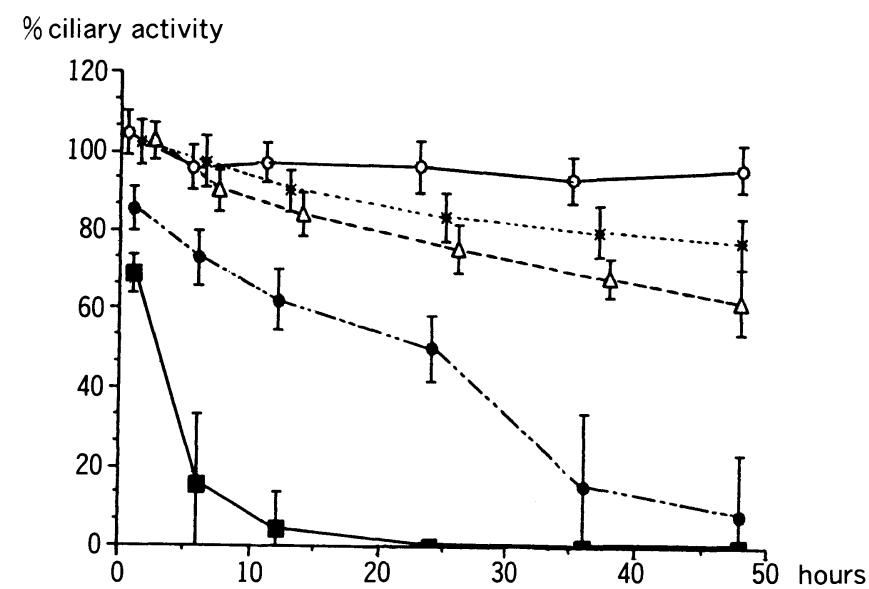

図1線毛運動数の経時的変化

対照群（ウイルスを含まない培養液中で培養した群 [○]）の線毛運 動数は 48 時間内には有意の変化を認めなかった. A 群 $\left(3.3 \times 10^{2}\right.$ $\mathrm{PFU} / \mathrm{ml}$ 中で培養 $[\mathrm{X}])$ の線毛運動数は48時間後には有意の低下を 示した. B群 $\left(3.3 \times 10^{4} \mathrm{PFU} / \mathrm{ml}[\triangle]\right), \mathrm{C}$ 群 $\left(3.3 \times 10^{6} \mathrm{PFU} / \mathrm{ml}[\bullet]\right)$ および D群 $\left(3.3 \times 10^{8} \mathrm{PFU} / \mathrm{ml}[\mathbf{\square}]\right)$ の線毛運動数はさらに早期よ り低下を示した。

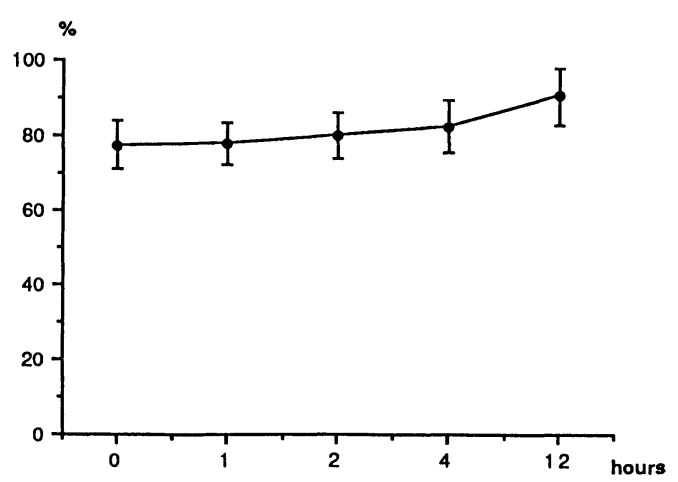

図 2 A 群の線毛運動数の回復 12時間の観察中に有意の回復は観察されなかった.

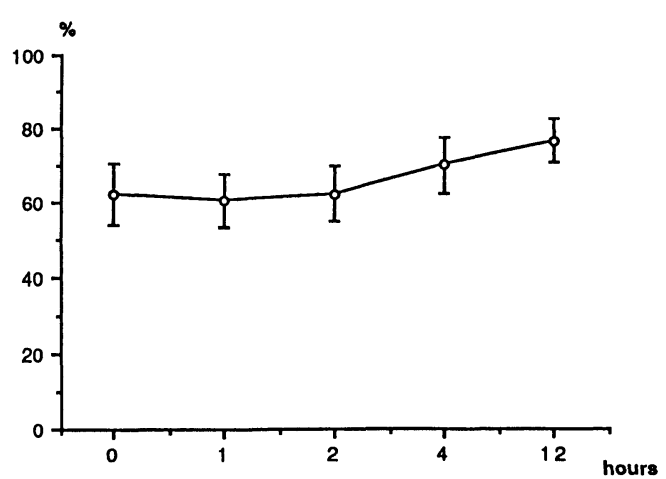

図 3 B 群の線毛運動数の回復 12時間の観察中に有意の回復は観察されなかった. 
の障害のいずれによってあ引き起てされうる 近年，粘液線毛系の構成因子の一つである線毛 機能の病態が滲出性中耳炎の転㷌や予後に深く 関与していることが報告されている14).すなわ ち，耳管鼓室口の線毛機能が良好に保持されて いる症例では非観血的な治療によって治癒しう ることが示されている.

そこで本研究においては，耳管線毛機能にイ ンフルエンザA ウイルスがどのような影響を及 ぼすかについて粘液層の影響を除外した実験系 を用いて検討した。本研究の成績より，インフ ルエンザ A ウイルスは耳管の線毛機能を低下さ せる作用を有するととが示されたが，その線毛 障害作用にはウイルスの濃度が大きく関与して いた。 また，インフルエンザAウイルスを含む 培養液中で48時間培養した場合には，洗浄によ っても速やかな機能改善は認められず，本ウイ ルスによる線毛機能障害は比較的長期にわたっ て持続することが示唆された. したがって，イ

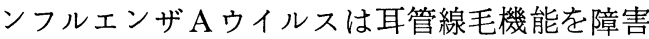
するととによって，耳管粘液線毛輸送を障害し うる可能性が示された.

しかし，本成績は粘液層の影響を除外した実 験系でなされたものであり，生体内においては 線毛機能は異なった反応を生じる可能性も否定 できない，すなわち，粘液層には大きな緩衝作 用のあるととが知られており，乙の緩衝作用に よって線毛機能の障害は本実験系で認められた 障害よりあかなり軽微であるととも考えられる. 逆に，インフルエンザ A ウイルスは実験動物の 耳管粘膜に感染を惹起しうることが実験的に示 されているので(5)16)，感染が引き金となり生体 内では種々の生理活性物質が遊離され，より強 く線毛障害の発現する可能性 ${ }^{17)}$ や粘液層の質的 変化を茇起しうる可能性む考えられる.

したがって，滲出性中耳炎などの中耳疾患に おけるインフルエンザウイルスの関与を解明す るためには，生体内にインフルエンザA ウイル スが侵入した際の粘液線毛系に対する影響を検 討する必要があるものと考えられる。
結語

臨床疫学的研究より，インフルエンザウイル スなどのウイルスが滲出性中耳炎などの中耳疾 患に関与しているてとが想像される．そこで，

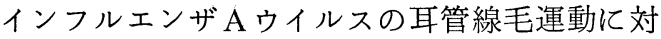
する直線的な影響を実験的に観察した，実験に は健常なモルモットより耳管中央部の粘膜上皮 の薄片を採取し，培養液 RPMI 1640 中で培養 した。 それぞれの培養粘膜片の最む運動性の高 い線毛運動を基準細胞とし，環境温度 $30^{\circ} \mathrm{C}$ で 線毛運動数（打／分）を測定した，次いで，培 養液を各種濃度のインフルエンザ A ウイルスを 含む培養液に置換し，基準細胞の経時的な線毛 運動数の時間的推移を 48 時間後まで観察した. また，対照としてインフルエンザAウイルスを 含まない培養液中で耳管線毛上皮を培養した。 比較的低濃度のウイルス中では線毛運動の低下 は軽度であったが, $3.3 \times 10^{6} \mathrm{PFU} / \mathrm{ml}$ 以上の培 養液中では数時間以内に線毛運動は著明に減少 し，36時間以上で線毛運動の停止屯観察された。 また，ウイルスを含む培養液中で48時間培養し た後に，ウイルスを洗浄して線毛運動の回復を 観察したが，12時間の観察中に運動性の回復は 観察されなかった。

\section{文献}

1) Lim DJ and DeMaria TF : Pathogenesis of otitis media; bacteriology and immunology. Laryngoscope $92:$ 278 286, 1982.

2 ) 茂木五郎：滲出性中耳炎の成因. JOHNS $1: 617$ $\sim 623,1985$.

3) Van Cauwenberge PB : Relevant and irrelevant predisposing factors in secretory otitis media. Acta Otolaryngol (Stockh) Suppl $414: 147 \sim 153$, 1984.

4) Henderson FW, Collier AM, Sanyal MA, et al : A longitudinal study of respiratory viruses and bacteria in the etiology of acute otitis media with effusion. N Engl Med 306 : 1377 1383, 1983.

5 ) Moore GE, Gerner RE and Franklin HA : Culture of normal human leukocytes. JAMA 199 : 519 524, 1967. 
6) Ohashi Y, Nakai Y, Koshimo H, et al : Ciliary activity in the in vitro tubotympanum. Arch Otorhinolaryngol $243: 317 \sim 319,1986$.

7) Ohashi Y and Nakai Y : Functional and morphological studies on chronic sinusitis mucous membrane 1 ; decline of ciliary action in chronic sinusitis. Acta Otolaryngol (Stockh) Suppl 397 : 3〜9, 1983.

8) Lim DJ, Paparella MM and Kimura RS : Ultrastructure of the eustachian tube and middle ear in the guinea pig. Acta Otolaryngol (Stockh) 63 : 425 444, 1967.

9) Ohashi Y, Nakai Y and Kihara S : Ciliary activity of the middle ear lining in guinea pigs. Ann Otol Rhinol Laryngol $94: 419 \sim 423,1985$.

10）大橋淑宏, 中井義明, 古下博之, 他: 二酸化窒素 暴露による実験的滲出性中耳炎の粘膜病態とそれ に及ぼすカルボシステインの効果に関する研究. 日耳鼻 $91: 71 \sim 87,1988$.

11) Ohashi $Y$, Nakai $Y$, Ikeoka $H$, et al : Functional disorder of eustachian tube in experimental otitis media with effusion following inoculation of bacterial endotoxin. Ann Otol Rhinol Laryngol $97: 422 \sim 426,1988$.

12) Kärja J, Nuutinen J and Karjalainen P : Mucociliary function in children with secretory otitis media. Acta Otolaryngol (Stockh) 95 : 544 546, 1983.

13) Wanner A : Clinical aspects of mucociliary transport. Am Rev Respir Dis 116 : 73 125, 1977.

14) Wacker DF and Howe ML : Middle ear ciliary activity as a determinant tympanostomy tube placement. Otolaryngol Head Neck Surg 95 : 434 437, 1986.

15) Giebink GS, Ripley ML and Wright PF : Eustachian tube histopathology during experimental influenza $\mathrm{A}$ virus infection in the chinchilla. Ann Otol Rhinol Laryngol 96 : 199 206, 1987.

16) Lim DJ, Bluestone CD, Klein JO, et al : Ultrastructural pathology of the tubotympanum following experimental influenza A virus induced otitis media. Recent Advance in Otitis Media. pp 436 438, BC Decker Inc, Toronto, Philadelphia, 1987.

17）杉浦欣一, 中井義明, 大橋淑宏, 他：ヒスタミン の中耳・耳管粘液線毛機能に及ぼす影響. Ear Res Jpn $20: 369 \sim 370,1989$.

$$
\left(\begin{array}{l}
\text { 原稿受付 : 平成 } 2 \text { 年 } 2 \text { 月 } 5 \text { 日 } \\
\text { 原稿採択 : 平成 } 2 \text { 年 } 2 \text { 月 } 20 \text { 日 } \\
\text { 別刷請求先 : 大橋淑宏 } \\
\text { T545 大阪市阿倍野区旭町1-5-7 } \\
\text { 大阪市立大学医学部耳鼻咽喉科学教室}
\end{array}\right)
$$

